\section{Effects of Root Pruning on Germinated Pecan Seedlings}

\author{
Rui Zhang, Fang-Ren Peng', Pan Yan, Fan Cao, \\ and Zhuang-Zhuang Liu \\ College of Forestry, Nanjing Forestry University, 159 Longpan Road, \\ Nanjing 210037, China
}

\begin{abstract}
Dong-Liang Le
College of Forestry, Nanjing Forestry University, 159 Longpan Road, Nanjing 210037, China; and Nanjing Green Universe Pecan Science and Technology Co. Ltd., 38 Muxuyuan Street, Nanjing 210007, China

Peng-Peng Tan

College of Forestry, Nanjing Forestry University, 159 Longpan Road, Nanjing 210037, China
\end{abstract}

Additional index words. Carya illinoinensis, taproot, lateral root, shoot growth

\begin{abstract}
Root systems of pecan trees are usually dominated by a single taproot with few lateral roots, which are commonly thought to inhibit successful transplanting. This study aimed to evaluate early growth and root/shoot development of pecan seedlings in response to taproot pruning. Taproots of 'Shaoxing' seedling pecan trees were mildly (1/3 of the total length of the radicle removed) and severely $(2 / 3$ of the total length of the radicle removed) pruned at different seedling development stages shortly after germination. At the end of the first growing season, top growth was measured and then trees were uprooted so that root system regrowth could be evaluated. The results showed that root pruning had no impact on increases in stem height or stem diameter. However, pruning the taproot could stimulate primary growth in taproot branches. Root weight and the number of taproot branches per tree increased with decreasing taproot length. This study indicated that severe root pruning when three to five leaves had emerged resulted in root systems with more taproot branches and the greatest root dry weight after one growth season, which may increase survival and reduce transplanting shock.
\end{abstract}

Pecan (Carya illinoinensis) is a deciduous nut tree that is well adapted to loamy bottom land sites (Sparks, 2002). Most pecan seeds are normally germinated and grown in field nurseries for one season, budded the second year, and then dug and sold as bare root trees. The root system predominantly consists of a taproot with weak lateral roots during the first year after pecan seed germination. The taproot will penetrate the soil up to 2 m unless stopped by a water table or an impervious layer by the first season's end. In contrast, lateral roots are typically limited and will not begin abundant development until the second year. Vertical roots develop from the primary lateral roots at least by the fourth year (Sparks, 2005). Pecan trees, in their native habitats, have been classified as a phreatophyte (a plant that characteristically roots to the water table) (Sparks, 2002). Failure to successfully transplant pecan trees is commonplace and could be a result of the lack of adequate lateral root formation. Newly planted trees may become established

We thank the Priority Academic Program Development of Jiangsu Higher Education Institutions (PAPD) and the Special Fund for Forest Scientific Research in the Public Welfare (201304711) for financial assistance.

${ }^{1}$ Corresponding author. E-mail: frpeng@njfu.edu.cn. if pruning the roots shortly after germination stimulates lateral root formation. Similarly, little work has been attempted to consider the effects of taproot pruning in young pecan seedlings back to different lengths on root regeneration. The objective of this study was to determine if root pruning at different periods after seed germination affects pecan seedling root and shoot growth and to evaluate different degrees of taproot pruning on root initiation.

\section{Materials and Methods}

The test was established at Lvzhou Pecan Research Station, Nanjing, China (lat. $32.05^{\circ} \mathrm{N}$, long. $118.77^{\circ} \mathrm{E}$ ). Open-pollinated seeds of the Chinese selection 'Shaoxing' were used as seed stock to produce seedlings. 'Shaoxing' had a small nut of very good quality with $\approx 50 \%$ percentage fill. The seeds averaged $30.4 \mathrm{~mm}$ in length, $20.9 \mathrm{~mm}$ in width, and $5.4 \mathrm{~g}$ in weight. Seeds were collected on 7 Nov. 2012, air-dried for $7 \mathrm{~d}$, and then packed in polyethylene bags and stored at $4{ }^{\circ} \mathrm{C}$ before treatment initiation. The seeds were soaked in running cold water for $48 \mathrm{~h}$ and then stratified in moist sand at $5^{\circ} \mathrm{C} \pm$ $2{ }^{\circ} \mathrm{C}$ for $60 \mathrm{~d}$ beginning on $20 \mathrm{Feb} .2013$, after which the seeds were transferred to a medium (5 peat: 3 vermiculite: 2 perlite by volume, Shanghai Jizhi Agricultural science and technology Co., Ltd., Shanghai, China) at $30{ }^{\circ} \mathrm{C}$ in the greenhouse to initiate germination. On 3 May 2013, 640 seedlings at stage I (Fig. 1-I) with a 1 - to $3-\mathrm{cm}$ emerging radicle were selected for the experiment and were individually placed $2 \mathrm{~cm}$ below the medium surface in each of the $15 \times 30$-cm containers filled with medium ( 5 peat: 3 vermiculite: 2 perlite by volume, Shanghai Jizhi Agricultural science and technology Co., Ltd., Shanghai, China). Four stages after stage I were selected for root pruning. At stage II (Fig. 1-II), the embryo emerged; the hypocotyl was short with a crooked tip and was white to reddish, while the radicle extended to 5 to $8 \mathrm{~cm}$ in length. At stage III (Fig. 1-III), acrospires that were small, tender, and reddish yellow emerged. The hypocotyl, turning reddish yellow to red-brown, became straight and grew rapidly to $\approx 10 \mathrm{~cm}$. The radicle was delicate, extending to 10 to 13 $\mathrm{cm}$. At stage IV (Fig. 1-IV), small, light green euphylla emerged. The hypocotyl
Table 1. Effect of radicle tip removal at different stages on the number of taproot branches, stem heights, and stem diameters of pecans.

\begin{tabular}{lccc}
\hline Stage & No. of taproot branches $^{\mathrm{x}}$ & ${\text { Stem ht }(\mathrm{cm})^{\mathrm{x}}}$ & ${\text { Stem diam }(\mathrm{mm})^{\mathrm{x}}}^{\mathrm{d}}$ \\
\hline $\mathrm{I}^{\mathrm{z}}$ & $1.0 \pm 0.0 \mathrm{~d}^{\mathrm{w}}$ & $22.8 \pm 4.5 \mathrm{a}$ & $6.1 \pm 1.4 \mathrm{a}$ \\
$\mathrm{II}^{\mathrm{y}}$ & $2.2 \pm 0.5 \mathrm{c}$ & $19.6 \pm 2.8 \mathrm{a}$ & $5.4 \pm 0.7 \mathrm{ab}$ \\
$\mathrm{III}^{\mathrm{y}}$ & $3.0 \pm 0.3 \mathrm{~b}$ & $19.6 \pm 4.2 \mathrm{a}$ & $5.7 \pm 0.8 \mathrm{ab}$ \\
IV $^{\mathrm{y}}$ & $3.3 \pm 0.4 \mathrm{~b}$ & $20.0 \pm 1.9 \mathrm{a}$ & $4.9 \pm 0.5 \mathrm{~b}$ \\
$\mathrm{~V}^{\mathrm{y}}$ & $5.7 \pm 0.5 \mathrm{a}$ & $22.4 \pm 4.1 \mathrm{a}$ & $6.0 \pm 1.1 \mathrm{a}$ \\
\hline
\end{tabular}

${ }^{\mathrm{z}}$ Radicle was not pruned.

${ }^{y}$ Root pruning with $2 / 3$ of the total length of the radicle removed.

${ }^{x}$ No. of taproot branches, stem height and stem diameter were investigated on 1 Sept. 2013. The data are shown as the mean value \pm SE.

wMeans within a column were separated using Tukey's test. Means followed by the same letter are not significantly different at $P \leq 0.05$. 
turned yellowish-green, became hardened and extended to $\approx 15 \mathrm{~cm}$. The taproot kept extending to $\approx 15 \mathrm{~cm}$, the upper taproot was semilignified with a few fibrous roots, and the lower taproot was still tender. At stage $\mathrm{V}$ (Fig. 1-V), three to five true leaves were visible. Shoot growth was slow, while the taproot kept extending from 17 to $20 \mathrm{~cm}$. More fibrous roots emerged on both the upper and lower taproots.

Expt. 1 was conducted to evaluate the effect of root pruning at different stages on pecan root and shoot growth. Treatments were randomly assigned to the developing seedlings: radicles were not cut, or $2 / 3$ of the total length of the radicle was removed at stage II (Fig. 1-II), stage III (Fig. 1-III), stage IV (Fig. 1-IV), and stage V (Fig. 1-V). An additional experiment was set up to evaluate the effects of different degrees of taproot pruning on root regeneration. Compared with Expt. 1, 1/3 of the total length of the radicle was removed at stage III (Fig. 1-III), stage IV (Fig. 1-IV), and stage V (Fig. 1-V). At each

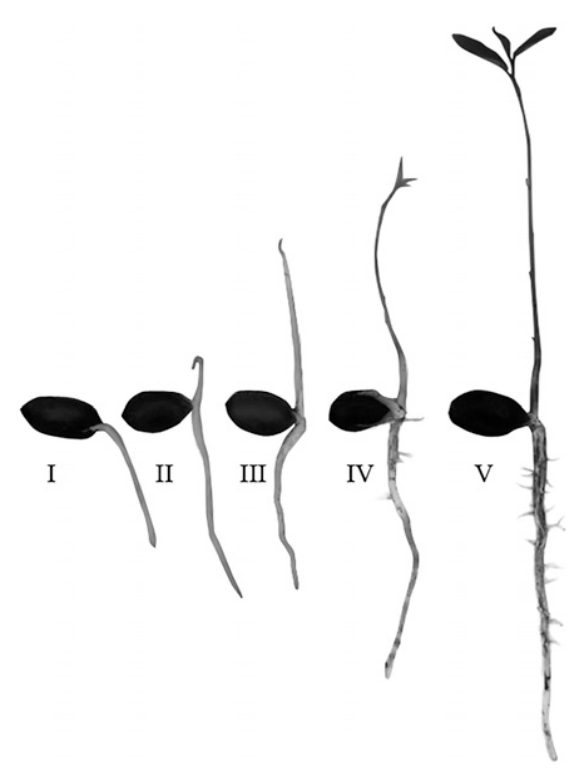

Fig. 1. Five different stages of pecan seedling growth following seed germination. (I) A radicle emerged on 3 May, ranging from 1 to $3 \mathrm{~cm}$ in length. (II) An embryo emerged on 8 May; hypocotyl was short, crooked and white to reddish in color. The radicle extended to 5 to $8 \mathrm{~cm}$ in length. (III) Acrospires emerged on 16 May and were small, tender, and reddish yellow. Hypocotyl, which changed from reddish yellow to red-brown, became straight and grew rapidly to $\approx 10 \mathrm{~cm}$. The radicle was delicate, extending to 10 to $13 \mathrm{~cm}$. (IV) Euphyllas emerged on 23 May. Two small, light green euphyllas were visible. The hypocotyl turned yellowish-green, became hardened, and extended to $\approx 15 \mathrm{~cm}$. The taproot continued extending to $\approx 15 \mathrm{~cm}$, the upper taproot was semilignified with a few fibrous roots, and the lower taproot was still tender. (V) Euphyllas expanded from 23 May to 28 May. Three to five true leaves were visible. Shoot growth was slow, while the taproot continued extending to 17 to $20 \mathrm{~cm}$. More fibrous roots emerged on both the upper and lower taproots. stage, containers were cut through the center with a razor blade. The medium was gently pushed aside to observe the radicles. Radicles were cut at the depth that was described. Containers were reattached with clear tape and then refilled with medium.

The experimental design was a randomized block with four replications, and each replication consisted of 20 seedlings. On 1 Sept., the seedling height was measured from the soil line to the growing point, while the stem diameter was measured with vernier calipers at a point $2.5 \mathrm{~cm}$ above the soil line. The seedlings were separated from the soil, and the number of taproot branches was recorded. The roots were washed for $3 \mathrm{~min}$ under running water, spread in a thin layer of water $(2-3 \mathrm{~mm})$ on a transparent tray and scanned by an Epson Expression/STD 1600 scanner (Seiko Epson, Nagano, Japan). The images were analyzed using WinRhizo commercial software (Regent Instruments, Quebec, QC). The surface areas of coarse roots (main lateral, $>2 \mathrm{~mm}$ in diameter at origin) and fine roots $(<2 \mathrm{~mm}$ in diameter) were measured and recorded. Stems (all tissue above the substrate) and roots were labeled, separated, and over-dried $\left(105^{\circ} \mathrm{C}\right)$ until they reached a constant weight, and then the dry weights were recorded. The data were subjected to analysis of variance, and where applicable, the means were separated by Tukey's test using Statistix (version 8.0; Analytical software, Tallahassee, FL).

\section{Results}

Root pruning had no effect on stem height or diameter at any stage except stage IV, in which the stem diameter was significantly smaller than that of seedlings that were pruned at other stages (Table 1). This study showed that the morphology of the root system and taproot branches were significantly affected by root pruning. All of the pruned seedlings produced branches, rather than a single taproot (Table 1). Root pruning at stages II, III, IV, and $\mathrm{V}$ on average produced 2.2, 3.0, 3.3, and 5.7 taproot branches, respectively, while nonroot-pruned seedlings kept only one single taproot (Table 1). Branches were generated at the cut after the taproot was pruned. The branches were tough, large-diameter roots that had reached $\approx 1 \mathrm{~cm}$ after 4 months of growth. In addition, a small compact fibrous root system was produced for all root-pruned seedlings.

Both shoot and root dry weights were slightly increased by root pruning at stages II and III (Fig. 2). However, root pruning at stage IV significantly decreased the shoot dry weight, while root pruning at stage $\mathrm{V}$ significantly increased both shoot and root dry weights (Fig. 2). The total dry weight was affected by root pruning. Root pruning at stage IV significantly decreased the total dry weight; however, the total dry weight was significantly increased when the root was pruned at stages II and V. Seedlings that were root pruned at stage $\mathrm{V}$ achieved the highest total dry weight, which was 1.37 times that of non-root-pruned seedlings.

In addition, root pruning had a significant influence on the surface area of both fine and coarse roots, which were two major components of the belowground system. Root pruning at stages II, III, IV, and V increased the surface area of fine roots by $35.0 \%, 59.4 \%$, $91.0 \%$, and $132.6 \%$, respectively (Fig. 3). Root pruning at stages II, III, IV, and V increased the surface area of coarse roots by $87.2 \%, 72.4 \%, 15.1 \%$, and $87.1 \%$, respectively (Fig. 3).

An additional experiment was conducted to evaluate the effect of two different degrees (mild and severe pruning) of radicle pruning on root generation. The results showed no significant difference between mild pruning

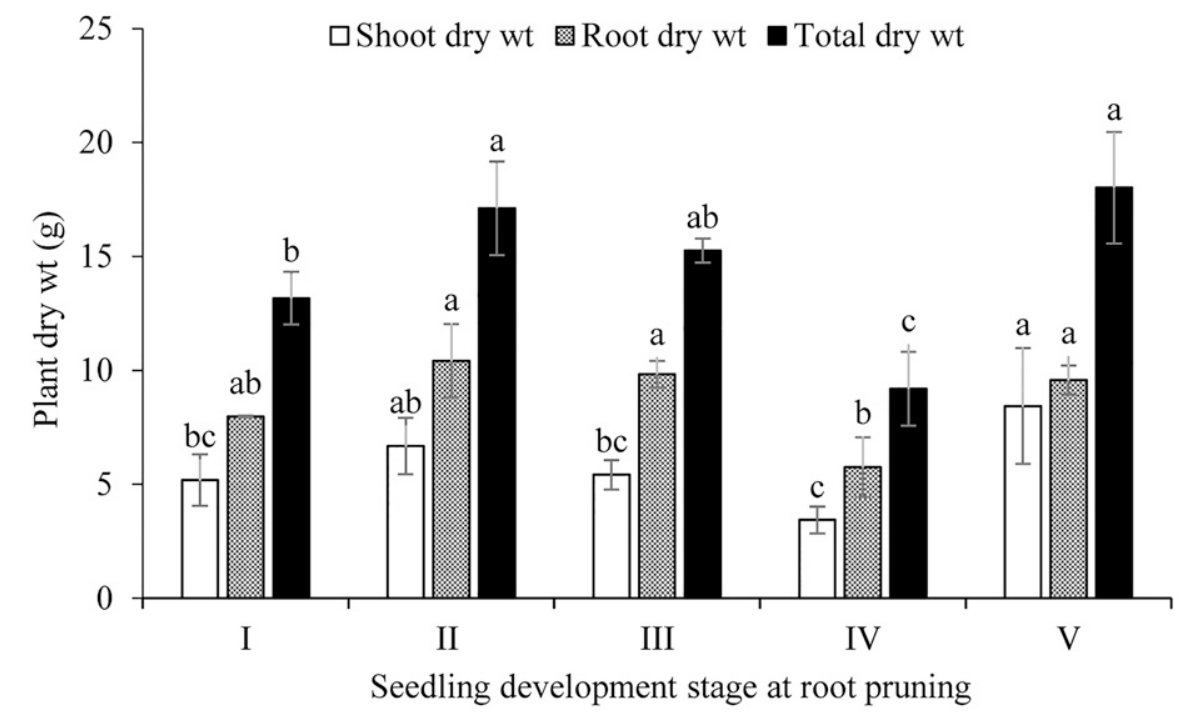

Fig. 2. Effect of root pruning at different development stages on first-year pecan seedling stem, root and total dry weight. Root pruning at each stage with $2 / 3$ of the total length of the taproot removed. Means within a weight series were separated using Tukey's test. Means followed by the same letter are not significantly different at $P \leq 0.05$. 
and severe pruning on shoot dry weight, root dry weight, stem height, and stem diameter (Table 2). However, the root system was affected by these two different pruning strategies. The number of taproot branches increased with decreasing taproot length (Table 2). Similar variation was observed on the surface area of fine and coarse roots. The surface area value of both fine and coarse roots of the severe pruned seedlings was significantly higher than that of seedlings that were mildly pruned at any stage except stage IV, when severe root pruning resulted in a slight decrease in the surface area of coarse roots (Fig. 4). Additionally, mild root pruning did not significantly increase the surface area of fine or coarse roots compared with non-root-pruned seedlings.

\section{Discussion}

Conflicting reports exist on the effect of root number on the long-term performance of out-planted pecan trees. Root pruning of seedling trees at a depth of $15 \mathrm{~cm} 3$ months after germination did not reduce tree growth in the nursery or increase the number of lateral roots or taproot branches or root quality (Laiche Jr, 1980). Laiche et al. (1983) reported that root pruning for 2-yearold seedlings at the time of transplant did not influence trunk height or weight, number of roots, or root weight. Similar results were reported by Wood (1996) for 3-year-old seedlings, although lateral roots proliferated at the base of the severed tap root. Other researchers have reported that taproot pruning stimulates top growth, root branching, and growth during the first 2 years after transplantation (McCraw and Smith, 1998). In a 2 -year study, pecan trees with a taproot that was pruned to 20 or $25 \mathrm{~cm}$ in length regenerated roots better and with a greater survival rate than trees pruned to a $76-\mathrm{cm}$ long taproot (Smith and Johnson, 1981). Our data showed that root pruning shortly after germination had no effect on aboveground growth in the first year, but significantly increased the taproot branches. Additionally, similar to previously published findings (Harris et al., 2001; McCraw and Smith, 1998), the number of taproot branches increased with decreasing taproot length (Table 2). Further investigation would be required to evaluate whether these new root systems with more taproot branches would hold on or affect aboveground growth for longer periods of time.

Early research (Finér et al., 2011; Lynch et al., 2013; McCormack et al., 2013) indicated that fine-root dynamics control a flux of carbon from plants and into soil and mediate the potential uptake and cycling of nutrients and water in terrestrial ecosystems. Our data suggested that root pruning could increase the surface area of both fine and coarse roots compared with non-root-pruned seedlings. Additionally, severely root-pruned seedlings had more fine-root surface area than seedlings that were mildly root pruned. Future research efforts can focus on the

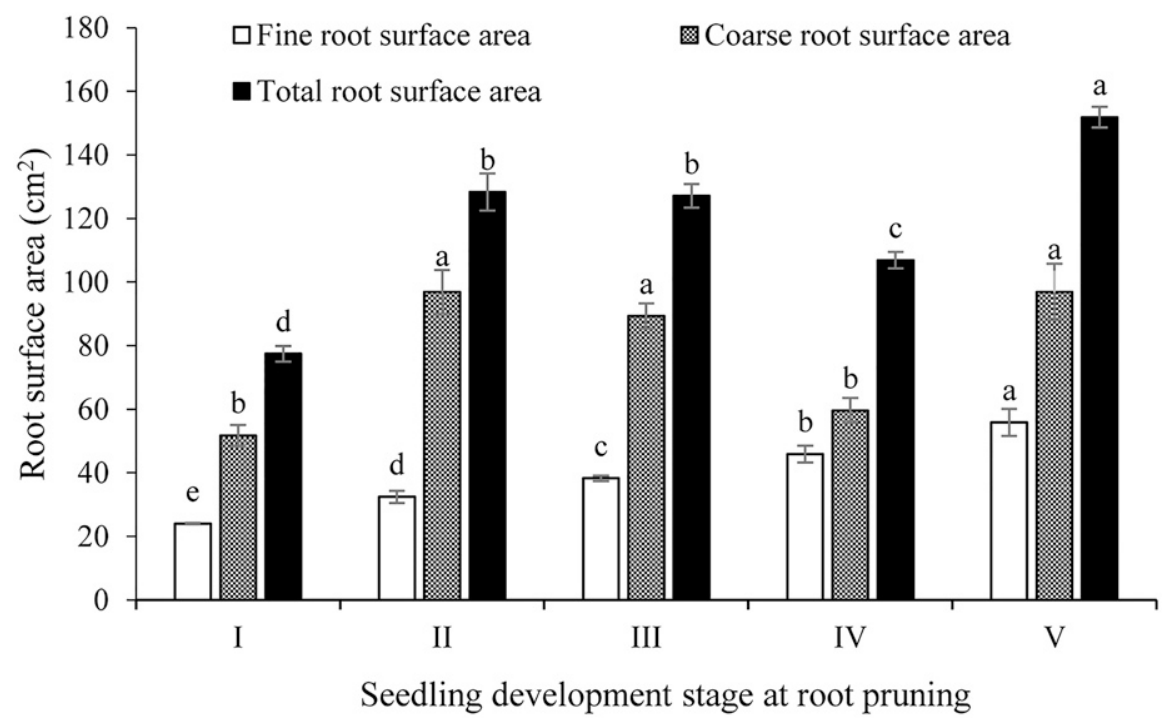

Fig. 3. Effects of root pruning at different development stages on root surface area. I: root was not pruned; II, III, IV and V: root pruning with $2 / 3$ of the total length of the taproot removed. Coarse roots: diameter $>2 \mathrm{~mm}$; fine roots: diameter $<2 \mathrm{~mm}$. Means within a surface area series were separated using Tukey's test. Means followed by the same letter are not significantly different at $P \leq 0.05$.

Table 2. Effects of different pruning treatments on pecan growth.

\begin{tabular}{|c|c|c|c|c|c|c|}
\hline Stage & $\begin{array}{l}\text { Pruning } \\
\text { treatment }^{\mathrm{z}}\end{array}$ & $\begin{array}{l}\text { No. of branches } \\
\text { of tap roots }{ }^{y}\end{array}$ & Shoot dry wt (g) & Root dry wt (g) & Stem ht $(\mathrm{cm})^{\mathrm{y}}$ & Stem diam $(\mathrm{cm})^{\mathrm{y}}$ \\
\hline$\overline{\mathrm{I}}$ & $\mathrm{N}$ & $1.0 \pm 0.0 \mathrm{~d}^{\mathrm{x}}$ & $5.2 \pm 1.1 \mathrm{bc}$ & $7.9 \pm 0.1 \mathrm{ab}$ & $22.8 \pm 4.5 \mathrm{ab}$ & $6.1 \pm 1.4 \mathrm{a}$ \\
\hline III & M & $1.7 \pm 0.5 \mathrm{c}$ & $5.3 \pm 1.2 \mathrm{bc}$ & $8.5 \pm 0.8 \mathrm{a}$ & $17.8 \pm 1.9 \mathrm{~b}$ & $5.6 \pm 0.7 \mathrm{ab}$ \\
\hline III & $\mathrm{S}$ & $3.0 \pm 0.9 b$ & $5.4 \pm 0.6 \mathrm{bc}$ & $9.8 \pm 0.6 \mathrm{a}$ & $19.6 \pm 2.8 \mathrm{ab}$ & $5.7 \pm 0.8 \mathrm{ab}$ \\
\hline IV & M & $1.8 \pm 0.4 \mathrm{c}$ & $5.5 \pm 0.4 \mathrm{bc}$ & $9.9 \pm 2.5 \mathrm{a}$ & $19.6 \pm 4.2 \mathrm{ab}$ & $5.3 \pm 1.2 \mathrm{ab}$ \\
\hline IV & $\mathrm{S}$ & $3.3 \pm 1.4 b$ & $3.4 \pm 0.6 \mathrm{c}$ & $5.8 \pm 1.3 b$ & $20.0 \pm 2.0 \mathrm{ab}$ & $4.9 \pm 0.5 b$ \\
\hline V & M & $1.8 \pm 0.7 \mathrm{c}$ & $7.1 \pm 1.3 \mathrm{ab}$ & $9.3 \pm 2.0 \mathrm{a}$ & $22.9 \pm 3.0 \mathrm{a}$ & $6.0 \pm 0.9 \mathrm{a}$ \\
\hline V & $\mathrm{S}$ & $5.7 \pm 0.1 \mathrm{a}$ & $8.4 \pm 2.5 \mathrm{a}$ & $9.6 \pm 0.6 \mathrm{a}$ & $22.4 \pm 4.1 \mathrm{ab}$ & $6.0 \pm 1.3 \mathrm{a}$ \\
\hline
\end{tabular}

${ }^{\mathrm{z}} \mathrm{N}$ : radicle was not pruned. M: mild pruning with $1 / 3$ of the total length of the radicle removed. S: severe pruning with $2 / 3$ of the total length of the radicle removed.

${ }^{y}$ No. of taproot branches, stem height, and stem diameter were investigated on 1 Sept. 2013. Stems and roots were separated and oven-dried $\left(105^{\circ} \mathrm{C}\right)$ until a constant weight, and then dry weights were recorded. The data are shown as the mean value $\pm \mathrm{SE}$.

'Means within a column were separated using Tukey's test. Means followed by the same letter are not significantly different at $P \leq 0.05$.
Fine roots

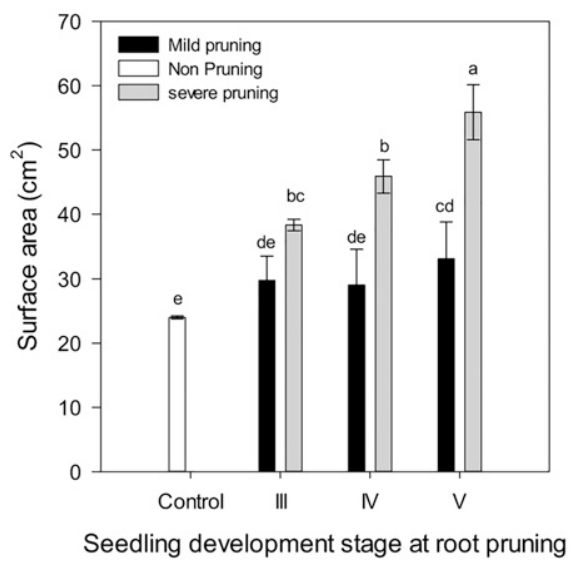

Coarse roots

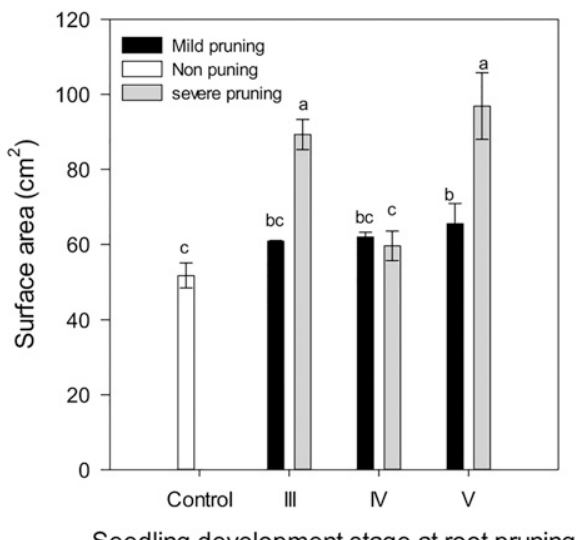

Fig. 4. Effect of two different degrees (mild and severe pruning) of radicle pruning on root surface area. Control means that the root was not pruned. Mild pruning means that $1 / 3$ of the total length of the radicle was removed. Severe pruning means that $2 / 3$ of the total length of the radicle was removed. Coarse roots: diameter $>2 \mathrm{~mm}$; fine roots: diameter $<2 \mathrm{~mm}$. Means within a surface area series were separated using Tukey's test. Means followed by the same letter are not significantly different at $P \leq 0.05$. 
understanding of the fine-root dynamics of pecan trees.

Shoot dry weight may comprise as little as $12 \%$ of the total dry weight of a 1 -year-old pecan seedling (White, 1980). Some research has indicated that because pecan trees are pheratophytes, there is a low probability of altering the root: shoot ratio by fertilization (Conner, 2006; White, 1980). This growth pattern was vital to pecan trees in its native sites especially when pecan trees were restricted by the vigorous growth of more competitive sympatric species (Fletcher et al., 2012; Sparks, 2002). In this study, data indicated that seedlings at our experiment site produced more shoot growth that accounted for as much as $35 \%$ to $46 \%$ of the plant total dry weight. This difference could have been a result of soil differences, e.g., texture, aeration, or water holding capacity, as suggested by Smith and Johnson (1981). These determinations were beyond the scope of this experiment.

In this study, our data showed that root pruning at stage IV had no benefit for seedling growth in terms of stem height, stem diameter, root dry weight, and shoot dry weight, although it could increase taproot branching. This indicated that stage IV may be a critical period, in which germinated pecan seedlings most likely cannot tolerate substantial root loss. For germinated seedlings, the cotyledons contain the stored food reserves of the seed. The cotyledon may be ephemeral, lasting only days after emergence, or may be persistent, enduring a year or more on the plant (Baraloto and Forget, 2007). As reported by Wetzstein et al. (1983), pecan seedling growth is dependent on cotyledonal lipids for the first 3 weeks after seed germination. We assume that as these reserves were depleted, seedlings could not obtain enough nutrients from the cotyledon during stage IV, which is presumed to be a transitional period when the first leaves begin to take over food production for seedlings by photosynthesis. Thus, taproot pruning at stage IV could be detrimental to seedling growth.

\section{Conclusions}

Generally, root pruning shortly after germination did not detrimentally affect the shoot growth of pecan seedlings, nor did it result in additional growth for the first year. However, pruning the taproot could stimulate the primary taproot branches, which may affect subsequent overall growth and may increase survival and reduce transplant shock. Severe root pruning with $2 / 3$ of the total length of the radicle removed generated more taproot branches and achieved a higher surface area value for both fine and coarse roots than that of mild root-pruned seedlings. The ideal time to prune the taproot is at stage $\mathrm{V}$ when three to five leaves have emerged, which may encourage the highest production of taproot branches and achieve the highest root and shoot dry weight after one season's growth. Root pruning at stage IV, which has been assumed to be a critical period for germinated seedlings to wean off of nutrition absorption from the cotyledon, would have negative effects on seedling growth.

\section{Literature Cited}

Baraloto, C. and P.M. Forget. 2007. Seed size, seedling morphology, and response to deep shade and damage in neotropical rain forest trees. Amer. J. Bot. 94:901-911.

Conner, P. 2006. Effects of nitrogen fertigation on first-year pecan seedling growth. HortScience 41:1062

Finér, L., M. Ohashi, K. Noguchi, and Y. Hirano. 2011. Fine root production and turnover in forest ecosystems in relation to stand and environmental characteristics. For. Ecol. Mgt. 262:2008-2023.

Fletcher, E.H., III, M. Thetford, J. Sharma, and S. Jose. 2012. Effect of root competition and shade on survival and growth of nine woody plant taxa within a pecan [Carya illinoinensis (Wangenh.) C. Koch] alley cropping system. Agrofor. Syst. 86:49-60.
Harris, J.R., A. Niemiera, J. Fanelli, and R. Wright. 2001. Root pruning pin oak liners affects growth and root morphology. HortTechnology 11:49-52.

Keever, G., G. Cobb, R. McDaniel, and A. Mukhopaphyay. 1986. Response of seedling pecan trees to container size and root pruning. Proc. SNA Res. Conf. 21:81-84.

Laiche, A.J., W.W. Kilby, and J.P. Overcash. 1983. Root and shoot growth of field-grown and container-grown pecan nursery trees 5 years after transplanting. HortScience 18:328-329.

Laiche, Jr., A.J. 1980. The effects of root pruning and seed size on nursery grown pecan trees. Pecan South 7:10-16.

Lynch, D.J., R. Matamala, C.M. Iversen, R.J. Norby, and M.A. Gonzalez. 2013. Stored carbon partly fuels fine-root respiration but is not used for production of new fine roots. New Phytol. 199:420-430.

Matta, F. and J. Storey. 1981. The effects of container design, $\mathrm{BA}$, and $\mathrm{GA}_{3}$ on root and shoot growth of seedling pecan trees [Carya illinoensis]. HortScience 16:652-653.

McCormack, M.L., D.M. Eissenstat, A.M. Prasad, and E.A. Smithwick. 2013. Regional scale patterns of fine root lifespan and turnover under current and future climate. Global Change Biol. 19:1697-1708.

McCraw, B. and M. Smith. 1998. Root pruning and soil type affect pecan root regeneration. HortTechnology 8:573-575.

Smith, M. and J. Johnson. 1981. The effect of top pruning and root length on growth and survival of transplanted pecan trees. Pecan Qrtly. 15:20-22.

Sparks, D. 2002. Rainfall governs pecan stand homogeneity in native, wild habitats. J. Amer. Soc. Hort. Sci. 127:860-868.

Sparks, D. 2005. Adaptability of pecan as a species. HortScience 40:1175-1189.

Wetzstein, H., D. Sparks, and G. Lang. 1983. Cotyledon detachment and growth of pecan seedlings. HortScience 18:331-333.

White, Jr., A.W. 1980. Effects of topsoil-subsoil fertilizer and lime amendments on top and root growth of 'Stuart' pecan seedlings in a simulated Norfolk soil profile. HortScience 17:380-381.

White, Jr., A.W. and J. Payne. 1982. Effects of root pruning on Stuart pecan trees. Pecan South 9:17-19.

Wood, B.W. 1996. Establishing pecan transplants. HortTechnology 6:276-279. 